\title{
Detection and Quantification of Potato virus Y Genomes in Single Aphid Stylets
}

\author{
M. Khelifa ${ }^{\dagger}$ \\ Fédération Nationale des Producteurs de Plants de Pomme de Terre/ Recherche, Développement et Promotion du Plant de \\ Pomme de Terre (FN3PT/RD3PT), 75008 Paris, France \\ Centre de Ressources Régionales en Biologie Moléculaire, Université de Picardie Jules Verne, 80039 Amiens Cedex 1, France
}

\begin{abstract}
Typically, the detection of a plant virus within its vector is carried out on the entire insect body. This process can be a possible source of confusion in the quantification of transmissible virus particles for styletborne viruses such as Potato virus $Y$ (PVY), since the transmissible virus fraction is the one only retained in the aphid vector's mouthparts. The objective of this study was to develop and validate the quantitative PCR method for the detection and quantification of PVY in the vector's stylet.

a significant amount of the virus is enclosed within the dissected stylets of Myzus persicae. Because this quantification only concerns the portion of the virus attached to the stylets, uniformity was observed in the recorded numbers of virus targets. This novel assay is applicable to several PVY strains as a rapid and sensitive detection method for use in PVY research and offers a convenient tool for deciphering the mechanism of Potyvirus acquisition.
\end{abstract} Using a specific method based on TaqMan chemistry with higher sensitivity than conventional reverse transcription PCR, this study reveals that
Keywords: absolute quantification, transmission, virus RNA copies
Potato virus $Y$ (PVY), a type member of the genus Potyvirus, is one of the most important viral pathogens affecting the yield and quality of potato production worldwide (Karasev and Gray 2013; Quenouille et al. 2013; Singh et al. 2008). PVY has a single-stranded positivesense RNA genome approximately $10 \mathrm{~kb}$ in size, which is translated into a single polyprotein cleaved into 10 multifunctional proteins (Dougherty and Carrington 1988). PVY isolates from potato strains are classified into seven strain groups $\left(\mathrm{PVY}^{\mathrm{O}}, \mathrm{PVY}^{\mathrm{C}}, \mathrm{PVY}^{\mathrm{N}}, \mathrm{PVY}^{\mathrm{NTN}}\right.$, $\mathrm{PVY}^{\mathrm{N}-\mathrm{Wi}}, \mathrm{PVY}^{\mathrm{E}}$, and $\mathrm{PVY}^{\mathrm{Z}}$ ) according to symptoms induced on tobacco and potato host plants and according to the presence or absence of recombination events in their genome (Glais et al. 2017; Green et al. 2018; Singh et al. 2008). Genomes of the $\mathrm{PVY}^{\mathrm{O}}$, PVY ${ }^{\mathrm{C}}$, and $\mathrm{PVY}^{\mathrm{N}}$ groups are nonrecombinant, whereas those of PVY ${ }^{\mathrm{NTN}}, \mathrm{PVY}^{\mathrm{N}-\mathrm{Wi}}$, $\mathrm{PVY}^{\mathrm{E}}$, and $\mathrm{PVY}^{\mathrm{Z}}$ are recombinants from the $\mathrm{PVY}^{\mathrm{N}}$ and $\mathrm{PVY} \mathrm{O}^{\mathrm{O}}$ parental strain groups (Boonham et al. 2002; Glais et al. 2002; Green et al. 2018; Lorenzen et al. 2008; Nie et al. 2004). Compared with the other recombinant PVY isolates, $\mathrm{PVY}{ }^{\mathrm{NTN}}$ and $\mathrm{PVY}^{\mathrm{N}-\mathrm{Wi}}$ isolates are considered as common recombinants found in many geographical locations (Green et al. 2017). Data collected in U.S. potato-growing regions showed a PVY strain composition shift from the previously dominant strain $\mathrm{PVY} \mathrm{Y}^{\mathrm{O}}$ to the two recombinant $\mathrm{PVY}^{\mathrm{NTN}}$ and $\mathrm{PVY}^{\mathrm{N}-\mathrm{Wi}}$ strains, and the latter has become the most prevalent strain (Funke et al. 2017). The reasons for these changes in the relative abundance of $\mathrm{PVY}$ can be interpreted as a strain-specific resistance against $\mathrm{PVY}$ exhibited by the varieties most used in potato field production areas (Funke et al. 2017; Rowley et al. 2015).

${ }^{\dagger}$ Corresponding author: M. Khelifa; mounia.khelifa@fnpppt.fr

Funding: This work was conducted as part of the Vegephy project funded by the Conseil Régional de Picardie and the Comptoir Commercial des Lubrifiants and SIPRE companies.

*The $\boldsymbol{e}$-Xtra logo stands for "electronic extra" and indicates that two supplementary figures and one supplementary table are published online.

The author(s) declare no conflict of interest.

Accepted for publication 3 April 2019.

(C) 2019 The American Phytopathological Society
This complex diversity within PVY species was highlighted using numerous methods, specifically reverse transcription (RT)-PCR and RT quantitative PCR (qPCR) developed to detect PVY in plants or tubers (Balme-Sinibaldi et al. 2006; Boonham et al. 2009; Chikh Ali et al. 2010, 2013; Glais et al. 1998, 2002; Jacquot et al. 2005; Kogovšek et al. 2008; MacKenzie et al. 2015; Nie et al. 2013; Rolland et al. 2008) and more recently using droplet digital PCR (Mehle et al. 2018). PVY is transmitted by more than 65 aphid species, including potato-colonizing and noncolonizing species (Nault 1997; Pelletier et al. 2012; Radcliffe and Ragsdale 2002; Ragsdale et al. 2001; Singh and Boiteau 1986; Verbeek et al. 2010), and its transmission efficiency depends on many factors among others aphid species, PVY isolates, and their host plants. Transmission tests assessed with several aphid species and PVY strains highlighted that Myzus persicae and Rhopalosiphum padi transmit PVY ${ }^{\mathrm{NTN}}$ isolates with the greatest efficiency followed by $\mathrm{PVY}^{\mathrm{O}}$ and $\mathrm{PVY} \mathrm{N}^{\mathrm{N}: \mathrm{O}}$ isolates (Mondal et al. 2016). PVY is transmitted in a nonpersistent manner (reviewed in Dietzgen et al. 2016) according to the "helper strategy," meaning that the viral helper protein HC-Pro (Pirone and Blanc 1996) mediates binding of virus particles to the vector stylets by forming an intermediary bridge. HC-Pro is a 50-kDa protein containing the conserved motif KITC at its N-terminal end (Robaglia et al. 1989) and PTK at its C-terminal end (Peng et al. 1998), which are involved in the binding to the aphid and to the consensus DAG motif of the coat protein, respectively (Blanc et al. 1997).

Improving our understanding of PVY transmission requires methods to detect the virus in the vector. To this end, various tools have been reported. Conventional RT-PCR techniques associated with different procedures allowing rapid viral RNA extraction were developed to detect PVY from a single aphid (Kim et al. 2016) and to define aphid species potentially able to acquire the virus (Singh et al. 1996).

A similar approach based on real-time PCR was developed by Olmos et al. (2005) for the quantitative detection of another Potyvirus species, the Plum pox virus (PPV), in single aphids. In this study, viral RNA targets were detected in individuals of the PPV vector $M$. persicae and the nonvector Aphis nerii, with a sensitivity 100 times greater than with conventional RT-PCR and 1,000 times higher than with the triple antibody sandwich enzyme-linked immunosorbent assay. One-step real-time RT-PCR was also developed to detect the persistently transmitted Barley yellow dwarf virus (BYDV) in single aphids, with detection and quantification ranging from $10^{2}$ to $10^{8}$ BYDV RNA copies. This confirms the high sensitivity of the technique compared with conventional RT-PCR (Fabre et al. 2003). 
Yet the viral detection assays described above were conducted using whole aphids and could therefore detect virus particles retained in the aphid stylets, as well as ingested virus particles remaining in the gut. However, for nonpersistent viruses, only viruses attached to the aphid stylets, and not those in the digestive tract, are transmitted (Powell 2005). This may be a source of confusion regarding the vector's ability to carry the virus and its capability for transmission. Zhang et al. (2013) highlighted this crucial difference and consequently developed a procedure to detect PVY in the stylets of a single aphid. Although this technique has enabled detection of the qualitative virus presence or absence within stylets using one-step conventional RT-PCR, it is not capable of obtaining quantitative parameters of the viral presence within aphid stylets. To address this issue, this study aims to improve the existing method of PVY detection in stylets by offering a more sensitive technique with a quantitative output to provide an opening for better understanding of the mechanism of virus acquisition.

\section{Materials and Methods}

Virus origin and aphids. Five previously characterized potato PVY isolates were used in this study (Table 1): one $\mathrm{PVY}^{\mathrm{N}}$ isolate (N605), one $\mathrm{PVY}^{\mathrm{NTN}}$ isolate $(\mathrm{FrOrl})$, one $\mathrm{PVY} \mathrm{O}_{-} \mathrm{O} 5$ isolate $(\mathrm{O}-$ 139), and two PVY ${ }^{\mathrm{N}-\mathrm{Wi}}$ isolates (Lw and Sp17) (Glais et al. 1996; Green et al. 2017, 2018; Jakab et al. 1997). These isolates were obtained from L. Glais of the French Federation of Seed Potato Growers (FN3PT). These isolates were maintained by mechanical inoculation on potato plants of cultivar Bintje or on Nicotiana tabacum 'Xanthi' under controlled conditions at $20 \pm 1{ }^{\circ} \mathrm{C}$, with $60 \pm 5 \%$ relative humidity under a $16-\mathrm{h} / 8$-h light/dark photoperiod.

The $M$. persicae aphid colony was initiated from a single apterous parthenogenetic female from a clone collected in 1999 in a potato field in Loos-en-Gohelle, France. Aphids were reared on 2- to 3week-old turnip plants (Brassica rapa L. var. rapa) in soil placed in 9-cm square plastic pots enclosed in Plexiglas cages and maintained in a growth room at $20 \pm 1^{\circ} \mathrm{C}$ under a $16-\mathrm{h} / 8$-h light/dark photoperiod to induce parthenogenesis. Adults obtained from larvae raised for 8 days on turnip leaves and kept on agar medium in Petri dishes were used for experiments.

Virus acquisition and stylet preparation. A group of starved $M$. persicae were allowed to probe the $\mathrm{PVY}^{\mathrm{NTN}}$ FrOrl-infected potato leaflet or a healthy control for 10 minutes as soon as they stopped moving. The virus amount acquired during aphid feeding was assumed to be highly dependent of the viral titer in the plant; thus, only one leaflet was used during acquisition to reduce variability in the virus amount acquired by the aphids (Rotenberg et al. 2009). The aphids were then collected and stored at $-20^{\circ} \mathrm{C}$ in $95 \%$ (vol/vol) ethanol (Zhang et al. 2013). Each aphid was dissected using miniforceps under a stereomicroscope (SteREO Discovery; Carl Zeiss) in order to separate the head from the stylets. The stylet bundle was removed from the proboscis and the stylets of each aphid, as well as the remaining body parts, were individually placed in a microcentrifuge tube. Both were kept at $-20^{\circ} \mathrm{C}$ for total RNA extraction.

Total RNA extraction from plants and aphids. The five PVY isolates were extracted from infected tobacco or potato plants 2 weeks after their mechanical inoculation. Two pooled symptomatic leaves were ground in liquid nitrogen, and total RNA was extracted using the RNeasy Plant Mini Kit (Qiagen) and subsequently eluted in $30 \mu l$ of nucleasefree water, according to the manufacturer's instructions.

RNA was extracted from the stylets and the aphid body using the NucleoSpin RNA XS kit (Macherey-Nagel). It was then eluted in

Table 1. Strain group, related classification publication, and GenBank accession numbers of Potato virus $Y$ isolates used in this study

\begin{tabular}{lccc}
\hline Isolate name & Strain group & GenBank accession no. & Reference \\
\hline FrOrl & NTN & AF228634 & Glais et al. 1996 \\
N605 & N & X97895 & Jakab et al. 1997 \\
O-139 & O5 & U09509 & Green et al. 2017 \\
Lw & N-Wi & AJ890349 & Green et al. 2018 \\
Sp17 & N-Wi & No data & Glais et al. 1996 \\
\hline
\end{tabular}

$15 \mu l$ of RNase-free water, according to the manufacturer's recommendations. The total RNA recovered from stylets was between 10 and $30 \mathrm{ng} / \mu \mathrm{l}$.

RT-PCR assay. Conventional RT-PCR was applied to detect PVY in plants (potato, tobacco) and in aphid stylets. The primers (forward Yo3S, reverse Yo4A), reaction mix, RT-PCR kit, and PCR program were as described by Zhang et al. (2013), except that 2 and $4 \mu$ l of total plant RNA extract and total stylet RNA extract were used, respectively. With this procedure, a PCR product of $480 \mathrm{bp}$ extending from nucleotides 8,717 to 9,196 of the coat protein (CP) gene (Singh and Singh 1996) was generated. A positive control (RNA extract from the PVY ${ }^{\mathrm{NTN}}$ FrOrl-infected plant and positive stylets) was included, and RNA extracted from the stylets of aphids maintained on uninfected plants was used as a negative control.

TaqMan primers and probe. Nucleotide sequences 8,717 to 9,196 of 18 coat protein genes of PVY isolates selected from the main PVY strain groups in the NCBI database (Green et al. 2017) were aligned using the BioEdit program and were compared with the homologous nucleotide sequence of the five PVY isolates sequenced in this study (N605, O-139, Lw, Sp17, and FrOrl) (Fig. 1). Within this sequence of 480 nucleotides, a narrow region corresponding to the central part of the CP gene (at positions 8,863 to 8,984) was precisely analyzed for selection of the primers and probe because it is known to be highly conserved between most PVY stain groups (MacKenzie et al. 2015). Thus, the optimal primers and probe for hybridization to all expected PVY isolates were designed from these sequence data using Primer Express software (Applied Biosystems). The selected CPF8869 (5'-GCATACGACATAGGAGAAACTGA-3') and CPR8977 (5'- CCATCATAACCCAAACTCCGT -3') primers amplified a 109-bp fragment (nucleotide positions according to the PVY ${ }^{\mathrm{N}}-605$ isolate; Jakab et al. 1997). The hydrolysis probe CPprobe8924 (5'-TGCATTGAAAATGGAACCTCGCCA-3') was labeled with the fluorescent dyes 6-carboxyfluorescein (FAM) on the $5^{\prime}$ end and Black Hole Quencher BHQ-1 on the $3^{\prime}$ end (MWG Biotech).

Preparation of PVY RNA standard. For absolute quantification, it is essential to use a standard curve with a known concentration of RNA target in order to transform the qPCR output of amplification cycles $(C p)$ into target copies. The RNA standard was obtained by in vitro transcription from the T7 RNA polymerase-dependent plasmid system as follows. One-step RT-PCR was performed on $2 \mu \mathrm{g}$ of total nucleic acid extracted from PVY ${ }^{\mathrm{NTN}}$ FrOrl-positive potato plants as described by Singh et al. (1996), using the One-Step RTPCR kit (Qiagen). A CP nucleotide sequence (480 bp) was reverse transcribed and amplified with forward primer $\mathrm{Y}^{\circ} 3 \mathrm{~S}^{\prime}$-ACGTCCAA AATGAGAATGCC-3' and reverse primer $\mathrm{Y}^{\circ} 4 \mathrm{~A} 5^{\prime}$-TGGTGTTC GTGATGTGACCT-3' (Singh et al. 1996), allowing amplification of a fragment located in the central position of the coat protein (CP), which is highly conserved between PVY stains (MacKenzie et al. 2015). The RT-PCR product was then purified from agarose gel using an Ultra Clean Gel Spin Purification kit (Mo Bio). Subsequently, $100 \mathrm{ng}$ of cDNA was inserted into TOPO TA cloning vector 2.1 (Invitrogen) according to the manufacturer's recommendations and cloned into Escherichia coli JM109 competent cells (Promega Inc.). Transformants were selected by ampicillin resistance in order to obtain the pTopoCP plasmid.

To generate a linear DNA template for run-off transcription, $0.5 \mu \mathrm{g}$ of pTopoCP plasmid template was digested with $1 \mathrm{U}$ of SpeI restriction enzyme (New England BioLabs Inc.). After complete digestion, the restriction enzyme was heat deactivated according to the manufacturer's recommendations. PVY RNA transcripts were synthesized using $10 \mathrm{U}$ of T7 RNA polymerase (SP6/T7 Transcription Kit; Roche Applied Science) in a $25-\mu 1$ reaction at $37^{\circ} \mathrm{C}$ for $1 \mathrm{~h}$, followed by DNase treatment and heat inactivation. The RNA was then phenol-chloroform extracted, ethanol precipitated, and resuspended in $20 \mu \mathrm{l}$ of RNase-free water. An additional treatment with Turbo DNA-free (Ambion) was performed to eliminate all remaining plasmid DNA. The PVY RNA concentration was then determined by spectrophotometry. A dilution from $45 \times 10^{7}$ to 45 copies of the RNA transcript was performed for the standard. 
Definition of PVY RNA copy number. The amount of standard RNA transcript quantified by a NanoDrop spectrophotometer (Thermo Scientific) was converted to a copy number by taking into account the molecular weight of an RNA nucleotide (340 Da), the fragment length ( 605 bases) of the in vitro transcript (extending from the T7 transcription factor to the SpeI restriction site), and the Avogadro constant $\left(6.023 \times 10^{23} \mathrm{molecules} / \mathrm{mol}\right)$ (Avogadro 1811). The copy number was calculated per $2.5 \mu 1$, the same volume used for the template in each real-time qRT-PCR. Ten-fold serial dilutions of in vitro RNA transcript were prepared (from $45 \times 10^{7}$ to 45 copies), aliquoted, and stored at $-80^{\circ} \mathrm{C}$ until use.

One-step real-time RT-PCR assay. Quantitative real-time RTPCR was performed with a LightCycler480 II (Roche Applied Science) on 384-well plates in a final volume of $10 \mu \mathrm{l}$ with $4 \mu \mathrm{l}$ of RNA extraction from stylets or $2.5 \mu$ l each of plant RNA and standard RNA transcript, added in LightCycler Multiplex RNA Virus Master mix (Roche Applied Science) and $500 \mathrm{nM}$ each of probe and specific sense and antisense primers. Two technical replicates were performed for each sample except for the viral transcripts, which were processed in triplicate. The thermocycler was programmed for $10 \mathrm{~min}$ of $\mathrm{RT}$ at $50^{\circ} \mathrm{C}$, followed by $30 \mathrm{~s}$ of initial denaturation at $95^{\circ} \mathrm{C}$, and finally 45 cycles at $95^{\circ} \mathrm{C}$ for $5 \mathrm{~s}, 60^{\circ} \mathrm{C}$ for $30 \mathrm{~s}$, and cooling at $40^{\circ} \mathrm{C}$ for $30 \mathrm{~s}$. Fluorescence intensity of the FAM dye was recorded during the amplification process in the "Single" mode. $C p$ values for each sample were calculated with LightCycler 480 software (version 1.5.1) using the absolute quantification/fit points method (Roche Applied Science). The slopes obtained from amplification of the successive RNA dilution series were used to calculate the efficiencies according to the following mathematical formula: slope $=-1 / \log$ (efficiency).

\section{Results}

Specificity of the real-time RT-PCR assay. According to in silico alignments achieved on the 18 PVY sequences (Fig. 1), primer CPF8869 and probe CPprobe8924 had a 1 to 2 mismatch with Adgen, PRI-509, PVY-MON, Ditta, 12-94, and MB112 sequences, which are positioned mostly in the central part of the primers and should not, in theory, prevent hybridization. For primer CPR8977, the mismatch observed on N605 and 12-94 should not prevent hybridization; in contrast, there could be some lack of attachment on TU-660 and N-Jg isolates, owing to a mutation in the $3^{\prime}$ primer region at position 20 of primer hybridization ( $\mathrm{T}$ instead of $\mathrm{C}$ ) and at

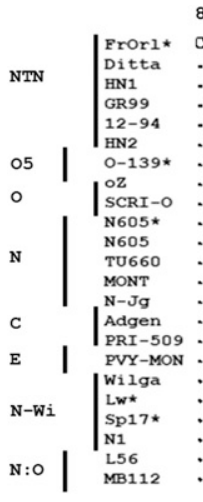

CPprobe8924

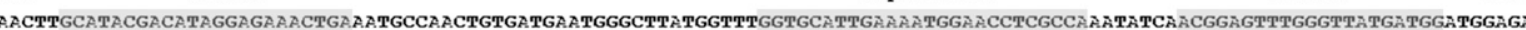

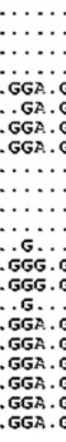

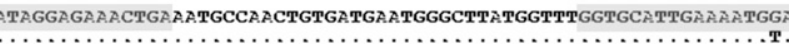

. $\ldots \ldots \ldots$.

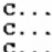

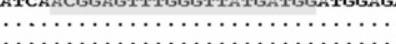

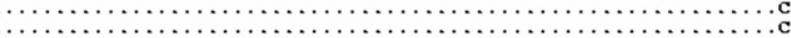

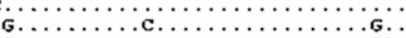

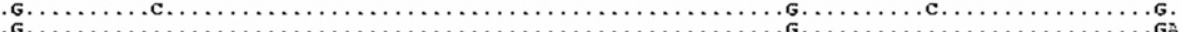

G.

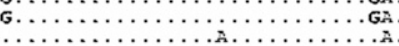

.

.

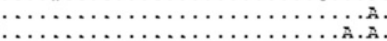

G.

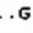

namband

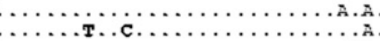

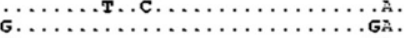

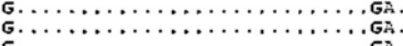

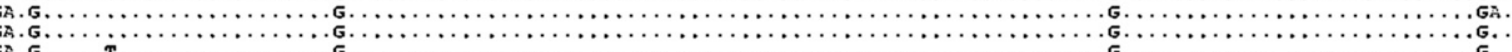

Fig. 1. Multiple alignment of Potato virus $Y(P V Y)$ capsid protein (CP) fragments between nucleotides 8,863 and 8,984 . The comparison was achieved using sequences retrieved from GenBank except for isolates with an asterisk, which are isolates sequenced as part of this study. Because a mutation was observed in the sequenced N605 isolate at nucleotide position 8,970 compared with the GenBank sequence, the two sequences are represented. Dots symbolize nucleotides that are present in all PVY sequences and are identical to those of PVY ${ }^{N T N}$ FrOrl isolate. Nucleotides that differ from the FrOrl sequence used as standard sequence are represented. Accession numbers are provided in parentheses for the following isolates: FrOrl (AF228634), 139 (U09509), Lw (AJ890349), Oz (EF026074), SCRI-O (AJ585196), N605 (X97895), Tu660 (AY166866), MONT (AY884983), N-Jg (AY166867), Adgen (AJ890348), PRI-509 (EU563512), PVY-MON (JF928458), Ditta (AJ890344), HN1 (HQ631374), GR99 (AJ890343), 12-94 (AJ889866), HN2 (GQ200836), Wilga (AJ890350), N1 (HQ912863), L56 (AY745492), and MB112 (AY745491). The nucleotide positions are based on the PVY 605 sequence (Jakab et al. 1997). Forward primer CPF8869, reverse primer CPR8977, and hybridization probe CPprobe8924 are indicated above in gray boxes and strain groups are shown on the left. Sequence alignment was processed using the BioEdit sequence alignment editor.

Table 2. Raw data for standard curves performed in triplicate on viral transcripts and plant RNA extracted from leaves infected with the PVYNTNFrOrl isolate giving amplification efficiency of $E=2.02$ and $E=1.98$, respectively

\begin{tabular}{|c|c|c|c|c|c|}
\hline Template & Sample & Theoretical concentration & Mean crossing point & Mean concentration & S.D. concentration \\
\hline \multirow[t]{9}{*}{ RNA transcript ${ }^{\mathrm{a}}$} & Dilution 1 & $45 \times 10^{7}$ & 15.12 & $45.74 \times 10^{7}$ & $27.81 \times 10^{6}$ \\
\hline & Dilution 2 & $45 \times 10^{6}$ & 18.21 & $52.95 \times 10^{6}$ & $13.27 \times 10^{6}$ \\
\hline & Dilution 3 & $45 \times 10^{5}$ & 21.65 & $48.21 \times 10^{5}$ & $17.33 \times 10^{5}$ \\
\hline & Dilution 4 & $45 \times 10^{4}$ & 24.83 & $50.47 \times 10^{4}$ & $12.28 \times 10^{4}$ \\
\hline & Dilution 5 & $45 \times 10^{3}$ & 28.26 & $44.51 \times 10^{3}$ & $36.05 \times 10^{2}$ \\
\hline & Dilution 6 & $45 \times 10^{2}$ & 31.57 & $45.21 \times 10^{2}$ & $14.47 \times 10^{2}$ \\
\hline & Dilution 7 & $22.5 \times 10^{2}$ & 33.49 & $13.10 \times 10^{2}$ & $94.88 \times 10$ \\
\hline & Dilution 8 & $45 \times 10$ & 34.36 & $79.60 \times 10$ & $62.97 \times 10$ \\
\hline & Dilution 9 & $4.5 \times 10$ & 38.30 & $3.84 \times 10$ & $0.57 \times 10$ \\
\hline \multirow[t]{6}{*}{ Plant RNA ${ }^{b}$} & Dilution 1 & 15 & 8.87 & 13.8830 & 2.9485 \\
\hline & Dilution 2 & 2.5050 & 11.22 & 2.7141 & 0.5496 \\
\hline & Dilution 3 & 0.4170 & 13.01 & 1.5258 & 2.0349 \\
\hline & Dilution 4 & 0.0694 & 16.32 & 0.0830 & 0.0349 \\
\hline & Dilution 5 & 0.0011 & 19.17 & 0.0113 & 0.0032 \\
\hline & Dilution 6 & 0.0019 & 21.68 & 0.0019 & 0.0003 \\
\hline
\end{tabular}

\footnotetext{
a Theoretical concentration and mean concentration values for RNA transcripts are presented as copy numbers per reaction.
}

b Theoretical concentration and mean concentration values for plant RNA are presented in nanograms per reaction. 
positions 14 and 17 for the PVY-MON isolate. The selected primers and probe appear to be suitable for detection of the other isolates. Amplified RNA extracted from infected leaves of the five PVY isolates (FrOrl, O-139, N605, Lw, and Sp17) confirms good amplification of each isolate with almost the same efficiencies $(1.98,1.98$, 1.97, 1.97, and 1.96, respectively; Supplementary Fig. S1), making this tool effective for detection of PVY strain groups N, NTN, O5, and N-Wi.

Sensitivity of the real-time RT-PCR. To determine the real-time RT-PCR sensitivity, 10-fold serial dilutions of the previously prepared transcript standards were made from $45 \times 10^{7}$ to 45 copies. The reliability of real-time RT-PCR using the viral transcript was

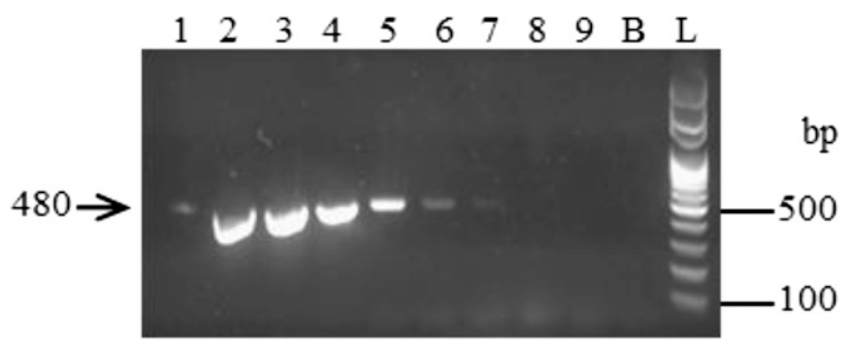

Fig. 2. Amplification efficiency using conventional reverse transcription PCR (RTPCR). Successive dilutions containing viral transcripts from $45 \times 10^{7}$ to 45 template molecules per reaction were amplified by one-step RT-PCR targeting the Potato virus $Y$ (PVY) coat protein gene. The amplification product was subjected to $1.2 \%$ agarose gel electrophoresis analysis. The arrow indicates the $480-\mathrm{pb}$ RTPCR product. $B=R T-P C R$ mix without matrix and $L=100-b p$ DNA ladder ready to load (Solis BioDyne).

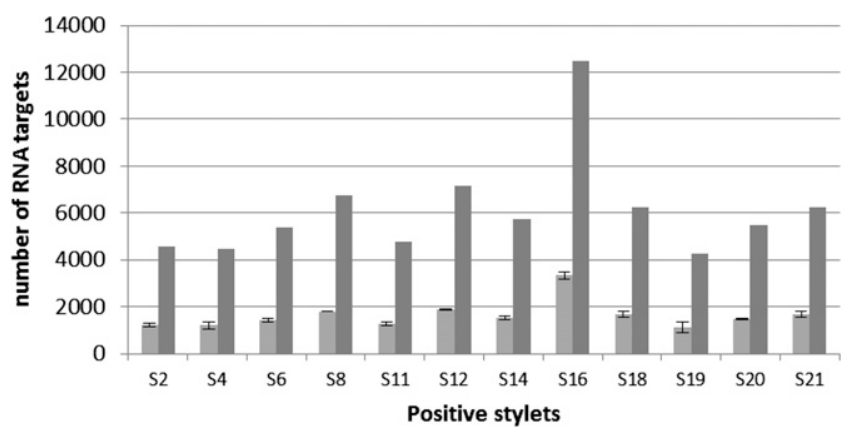

Fig. 3. Absolute quantification of RNA targets in aphid stylets after 10-min acquisition on a Potato virus $Y(P V Y)$-infected leaf. The mean number of RNA targets recorded in $4 \mu \mathrm{l}$ of extracted RNA is shown for each positive stylet (light gray bars), with the standard error between technical duplicates. The dark bars represent an estimate of the number of targets in whole stylets ( $15 \mu$ l of RNA extraction). then tested in an experiment conducted with three repetitions of each sample.

The standard curve revealed a high amplification efficiency $(E=$ 2.02 ), which is in the range of $45 \times 10^{7}$ to 45 viral RNA copies per reaction (Table 2). In our conditions, the detection threshold was fixed to 45 copies; since the amplification efficiency was around $100 \%$, it was possible to estimate the copy number with high reliability.

The amplification efficiencies of the standards and PVY-infected aphid stylets were compared according to Rieu and Powers (2009). Successive RNA dilutions could not be made because of the low amount of RNA extracted from the stylets; therefore, RNA extracted from leaves infected with the PVY isolates was used as an alternative, giving an efficiency of around 1.98 (Table 2), which is close to the standard efficiency value.

Sensitivity of the conventional RT-PCR. The previously prepared transcript diluted from $45 \times 10^{7}$ to 45 copies (Table 2) was subjected to conventional RT-PCR. Electrophoresis analysis revealed no detection using the more concentrated sample (Fig. 2; lane 1). By contrast, we observed a 480-bp product with a decreasing intensity corresponding to viral transcripts from $45 \times 10^{6}$ to $22.5 \times 10^{2}$ template molecules per reaction and nothing below the latest value corresponding to $45 \times 10$ and 45 template molecules per reaction (Fig. 2; lanes 8 and 9).

Detection in stylets using the real-time RT-PCR assay. RNA samples extracted from stylets of healthy aphids or aphids fed on PVY ${ }^{\text {NTN }}$ FrOrl-infected plants were used as templates and samples from healthy or PVY-infected plants were included as controls. The amplification plot shows that only RNA extracted from PVYinfected plants and from aphids that had fed on the same infected plant (Supplementary Fig. S2) could be detected. Amplification in the stylet sample curve was slightly delayed owing to the small amount of virus enclosed in the sample compared with the infected plant. As expected, RNA from healthy plants and aphids fed on the same plants was not amplified.

Quantification of viral targets was performed on stylets from 21 aphids after 10 min of acquisition on the PVY-infected leaflet (Supplementary Table S1). Of the tested aphids, 12 (57\%) were positively amplified. Among the 12 stylets detected positively in PVY, all presented a number of targets between 1,141 to 1,904 copies, except for one stylet that reached 3,327 copies (Fig. 3). Otherwise, the total volume of RNA extracted from the stylet could be used to estimate the total amount of virus enclosed in each stylet, and the value oscillated between 4,000 and 12,300 RNA targets (Fig. 3).

The same RNAs used for quantification were then subjected to conventional RT-PCR detection. The signal generated from the amplification product staining at $480 \mathrm{pb}$ (Fig. 4) provided low intensity because of the small virus amount enclosed in the stylets, unlike the PVY-infected leaf that served as a positive control (Fig. 4; lane Pp). PVY was detected on eight stylets (Fig. 4; lanes 4, 6, 7, 8, 11, 18, 19, and 21 ), representing $38 \%$ of the total sample. Surprisingly, stylet

$\mathrm{bp}$
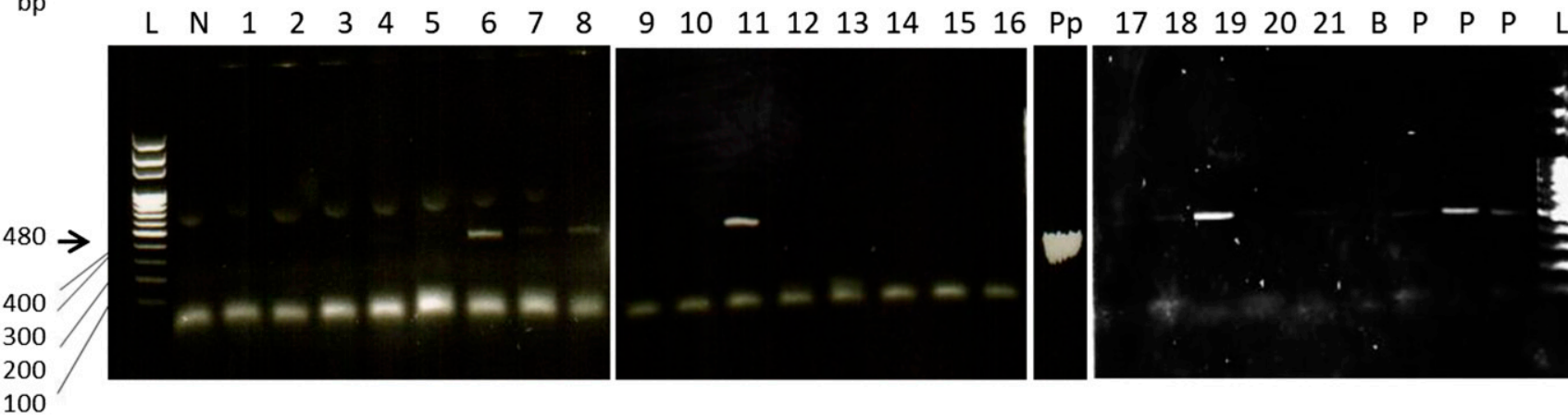

Fig. 4. The $1.2 \%$ agarose gel electrophoresis analysis showing detection of Potato virus $Y(P V Y)$ from the stylets of single Myzus persicae using a one-step reverse transcription PCR (RT-PCR) assay targeting the PVY coat protein gene. Lanes 1 to 21 are different individual stylets. The arrow indicates the 480-pb RT-PCR product. N = negative control, Pp = positive control (PVY-infected plant), $B=$ RT-PCR mix without matrix, $P=$ positive control (PVY-infected aphids), and $L=100-b p$ DNA ladder ready to load (Solis BioDyne). 
study, quantification of PVY RNA copies was only achieved on a small part of RNA extracted from the stylets; extrapolating the estimate to the whole fraction suggests that the RNA target number could range from 4,000 to 12,300 copies. A plausible explanation for the much greater variability observed in previous studies is that the authors did not discern between styletborne and ingested viruses. Pirone and Thornbury (1988) detected between 15 and more than 20,000 virions in individual aphids fed on ${ }^{125}$ I-labeled Tobacco vein mottling virus particles. Similarly, the number of PPV targets carried by individual $M$. persicae or $A$. nerii insects was reported to range from 40 to 2,381 (Olmos et al. 2005). In this study, comparing target numbers recorded in stylets to aphid bodies revealed a greater number in the bodies (Tables 3 and 4). Moreover, it was observed in a nonnegligible number $(44.82 \%)$ of tested aphids that the body carried the virus, whereas no virus was detected in the corresponding stylets. This result may be attributable to a lack of transmission complex formation in the stylets during feeding. Interestingly, the same observation was made by Zhang et al. (2013), who reported that the virus was detected in all aphid bodies and only in $70 \%$ of the tested stylets after a sustained feeding period of $R$. padi on potato PVY-infected potato leaves, which means that the virus was not always retained in the stylets or was at a concentration below the detectable limit. This suggests that the number of viruliferous aphids could be overestimated by quantifying the virus in the whole insect. Considering the large number of viral copies found in the stylets after acquisition, it is important to determine the epidemiological significance of these values, since only a few PVY viral particles are sufficient to initiate infection (Moury et al. 2007). Indeed, using a mathematical model, Moury et al. (2007) focused on population bottlenecks during horizontal transmission and determined that an average release of 0.5 to 3.2 viral particles by aphids was sufficient to initiate plant infection, which is extremely low compared with the value recorded from the stylets in the present study.

This method enables substantial time-savings through the complete elimination of the period occurring between virus inoculation by the vector and the appearance of foliar symptoms and could help to determine the efficiency of virus acquisition between several vectors. It could also be an effective tool to screen candidate molecules that block the interaction between the virus and its receptor within the vector (e.g., mineral oil as well as molecules that act as potential antivirals). In addition to improving the sensitivity of existing techniques, the method described here will provide a useful tool for understanding the mechanisms of PVY acquisition.

\section{Acknowledgments}

The author thanks Laurent Glais and Martin Drucker for critical reading of the manuscript and once again Laurent Glais from FN3PT/RD3PT for providing PVY isolates. The author is indebted to the Bioécologie des Insectes Phytophages et Entomophages laboratory for providing the aphid clone and Brandon Loveall of Improvence for English proofreading services.

\section{Literature Cited}

Ammar, E. D., Jarlfors, U., and Pirone, T. P. 1994. Association of Potyvirus helper component protein with virions and the cuticle lining the maxillary food canal and foregut of an aphid vector. Phytopathology 84:1054-1060.

Avogadro, A. 1811. Essai d'une manière de déterminer des masses relatives des molécules élémentaires des corps, et les proportions selon lesquelles elles entrent dans ces combinaisons. J. Phys. 73:58-76.

Balme-Sinibaldi, V., Tribodet, M., Croizat, F., Lefeuvre, P., Kerlan, C., and Jacquot, E. 2006. Improvement of Potato virus $Y$ (PVY) detection and quantitation using $\mathrm{PVY}^{\mathrm{N}}$ - and $\mathrm{PVY}^{\mathrm{O}}$-specific real-time RT-PCR assays. J. Virol. Methods 134:261-266.

Berger, P. H., and Pirone, T. P. 1986. The effect of helper-component on the uptake and localization of potyviruses in Myzus persicae. Virology 153:256-261.

Blanc, S., Drucker, M., and Uzest, M. 2014. Localizing viruses in their insect vectors. Annu. Rev. Phytopathol. 52:403-425.

Blanc, S., Lopez-Moya, J. J., Wang, R., Garcia-Lampasona, S., Thornbury, D. W., and Pirone, T. P. 1997. A specific interaction between coat protein and helper component correlates with aphid transmission of a potyvirus. Virology 231: 141-147.

Boonham, N., Laurenson, L., Weekes, R., and Mumford, R. 2009. Direct detection of plant viruses in potato tubers using real-time PCR. Pages 249-258 in: Plant Pathology: Techniques and Protocols. R. Burns, ed. Humana Press, Totowa, NJ.
Boonham, N., Walsh, K., Preston, S., North, J., Smith, P., and Barker, I. 2002. The detection of tuber necrotic isolates of Potato virus $\mathrm{Y}$, and the accurate discrimination of $\mathrm{PVY}^{\mathrm{O}}, \mathrm{PVY}^{\mathrm{N}}$ and $\mathrm{PVY}^{\mathrm{C}}$ strains using RT-PCR. J. Virol. Methods 102:103-112.

Bradley, R. H. 1966. Which of an aphid's stylets carry transmissible virus? Virology 29:396-401.

Chikh Ali, M., Maoka, T., Natsuaki, K. T., and Natsuaki, T. 2010. The simultaneous differentiation of Potato virus $\mathrm{Y}$ strains including the newly described strain PVY ${ }^{\text {NTN-NW }}$ by multiplex PCR assay. J. Virol. Methods 165:15-20.

Chikh Ali, M. C., Karasev, A. V., Furutani, N., Taniguchi, M., Kano, Y., Sato, M., Natsuaki, T., and Maoka, T. 2013. Occurrence of Potato virus Y strain $\mathrm{PVY}^{\mathrm{NTN}}$ in foundation seed potatoes in Japan, and screening for symptoms in Japanese potato cultivars. Plant Pathol. 62:1157-1165.

Dietzgen, R. G., Mann, K. S., and Johnson, K. N. 2016. Plant virus-insect vector interactions: Current and potential future research directions. Viruses 8:303.

Dougherty, W.G., and Carrington, J.C. 1988. Expression and function of potyviral gene products. Ann. Rev. Phytopathol. 26:123-143.

Fabre, F., Kervarrec, C., Mieuzet, L., Riault, G., Vialatte, A., and Jacquot, E. 2003. Improvement of Barley yellow dwarf virus-PAV detection in single aphids using a fluorescent real time RT-PCR. J. Virol. Methods 110:51-60.

Funke, C. N., Nikolaeva, O. V., Green, K. J., Tran, L. T., Chikh-Ali, M., QuinteroFerrer, A., Cating, R. A., Frost, K. E., Hamm, P. B., Olsen, N., Pavek, M. J., Gray, S. M., Crosslin, J. M., and Karasev, A. V. 2017. Strain-specific resistance to Potato virus $\mathrm{Y}$ (PVY) in potato and its effect on the relative abundance of PVY strains in commercial potato fields. Plant Dis. 101: 20-28.

Glais, L., Bellstedt, D. U., and Lacomme, C. 2017. Diversity, characterisation and classification of PVY. Pages 43-76 in: Potato virus $Y$ : Biodiversity, Pathogenicity, Epidemiology and Management. C. Lacomme, L. Glais, D. Bellstedt, B. Dupuis, A. Karasev, and E. Jacquot, eds. Springer, Cham, Switzerland.

Glais, L., Kerlan, C., Tribodet, M., Tordo, V. M.-J., Robaglia, C., and AstierManifacier, S. 1996. Molecular characterization of potato virus YN isolates by PCR-RFLP. Eur. J. Plant Pathol. 102:655-662.

Glais, L., Tribodet, M., Gauthier, J. P., Astier-Manifacier, S., Robaglia, C., and Kerlan, C. 1998. RFLP mapping of the whole genome of ten viral isolates representative of different biological groups of potato virus Y. Arch. Virol. 143:2077-2091.

Glais, L., Tribodet, M., and Kerlan, C. 2002. Genomic variability in Potato potyvirus Y (PVY): Evidence that PVY ${ }^{\mathrm{NW}}$ and $\mathrm{PVY} \mathrm{NTN}^{\mathrm{NT}}$ variants are single to multiple recombinants between $\mathrm{PVY}^{\mathrm{O}}$ and $\mathrm{PVY}^{\mathrm{N}}$ isolates. Arch. Virol. 147:363-378

Green, K. J., Brown, C. J., Gray, S. M., and Karasev, A. V. 2017. Phylogenetic study of recombinant strains of Potato virus Y. Virology 507:40-52.

Green, K. J., Brown, C. J., and Karasev, A. V. 2018. Genetic diversity of potato virus Y (PVY): Sequence analyses reveal ten novel PVY recombinant structures. Arch. Virol. 163:23-32.

Jacquot, E., Tribodet, M., Croizat, F., Balme-Sinibaldi, V., and Kerlan, C. 2005. A single nucleotide polymorphism-based technique for specific characterization of $\mathrm{Y}^{\mathrm{O}}$ and $\mathrm{Y}^{\mathrm{N}}$ isolates of Potato virus Y (PVY). J. Virol. Methods 125:83-93.

Jakab, G., Droz, E., Brigneti, G., Baulcombe, D., and Malnoë, P. (1997). Infectious in vivo and in vitro transcripts from a full-length cDNA clone of PVY-N605, a Swiss necrotic isolate of potato virus Y. J Gen Virol. 78:3141-3145.

Karasev, A. V., and Gray, S. M. 2013. Continuous and emerging challenges of Potato virus $\mathrm{Y}$ in potato. Annu. Rev. Phytopathol. 51:571-586.

Kim, J., Cha, D. J., Kwon, M., and Maharjan, R. 2016. Potato virus Y (PVY) detection in a single aphid by one-step RT-PCR with boiling technique. Entomol. Res. 46:278-285.

Kogovšek, P., Gow, L., Pompe-Novak, M., Gruden, K., Foster, G. D., Boonham, N., and Ravnikar, M. 2008. Single-step RT real-time PCR for sensitive detection and discrimination of Potato virus $\mathrm{Y}$ isolates. J. Virol. Methods 149:1-11.

Lorenzen, J., Nolte, P., Martin, D., Pasche, J. S., and Gudmestad, N. C. 2008. NE11 represents a new strain variant class of Potato virus Y. Arch. Virol. 153: 517-525.

MacKenzie, T. D., Nie, X., and Singh, M. 2015. RT-PCR and real-time RT-PCR methods for the detection of potato virus $\mathrm{Y}$ in potato leaves and tubers. Methods Mol. Biol. 1236:13-26.

Martín, B., Fereres, A., Tjallingii, W. F., and Collar, J. L. 1997. Intracellular ingestion and salivation by aphids may cause the acquisition and inoculation of non-persistently transmitted plant viruses. J. Gen. Virol. 78:2701-2705.

Mehle, N., Dobnik, D., Ravnikar, M., and Pompe Novak, M. 2018. Validated reverse transcription droplet digital PCR serves as a higher order method for absolute quantification of Potato virus Y strains. Anal. Bioanal. Chem. 410 3815-3825.

Mondal, S., Wenninger, E. J., Hutchinson, P. J. S., Whitworth, J. L., Shrestha, D., Eigenbrode, S. D., and Bosque-Pérez, N. A. 2016. Comparison of transmission efficiency of various isolates of Potato virus Y among three aphid vectors. Entomol. Exp. Appl. 158:258-268.

Moury, B., Fabre, F., and Senoussi, R. 2007. Estimation of the number of virus particles transmitted by an insect vector. Proc. Natl. Acad. Sci. USA 104 17891-17896. 
Nault, L. 1997. Arthropod transmission of plant viruses: A new synthesis. Ann. Entomol. Soc. Am. 90:521-541.

Nie, X., Singh, M., Pelletier, Y., and McLaren, D. 2013. Recent advances on Potato virus Y research in Canada. Am. J. Potato Res. 90:14-20.

Nie, X., Singh, R. P., and Singh, M. 2004. Molecular and pathological characterization of $\mathrm{N}: \mathrm{O}$ isolates of the Potato virus $\mathrm{Y}$ from Manitoba, Canada. Can Plant Pathol 26:573-583.

Olmos, A., Bertolini, E., Gil, M., and Cambra, M. 2005. Real-time assay for quantitative detection of non-persistently transmitted Plum pox virus RNA targets in single aphids. J. Virol. Methods 128:151-155.

Pelletier, Y., Nie, X., Giguère, M. A., Nanayakkara, U., Maw, E., and Foottit, R. 2012. A new approach for the identification of aphid vectors (Hemiptera: Aphididae) of potato virus Y. J. Econ. Entomol. 105:1909-1914.

Peng, Y. H., Kadoury, D., Gal-On, A., Huet, H., Wang, Y., and Raccah, B. 1998. Mutations in the HC-Pro gene of zucchini yellow mosaic potyvirus: Effects on aphid transmission and binding to purified virions. J. Gen. Virol. 79:897-904.

Pirone, T. P., and Blanc, S. 1996. Helper-dependent vector transmission of plant viruses. Annu. Rev. Phytopathol. 34:227-247.

Pirone, T. P., and Thornbury, D. W. 1988. Quantity of virus required for aphid transmission of a potyvirus. Phytopathology 78:104-107.

Powell, G. 2005. Intracellular salivation is the aphid activity associated with inoculation of non-persistently transmitted viruses. J. Gen. Virol. 86:469-472.

Quenouille, J., Vassilakos, N., and Moury, B. 2013. Potato virus Y: A major crop pathogen that has provided major insights into the evolution of viral pathogenicity. Mol. Plant Pathol. 14:439-452.

Radcliffe, E. B., and Ragsdale, D. W. 2002. Aphid-transmitted potato viruses: The importance of understanding vector biology. Am. J. Potato Res. 79:353-386.

Ragsdale, D. W., Radcliffe, E. B., and DiFonzo, C. D. 2001. Epidemiology and field control of PVY and PLRV. Pages 237-270 in: Virus and Virus-Like Diseases of Potatoes and Production of Seed-Potatoes. G. Loebenstein, P. H. Berger, A. A. Brunt, and R. H. Lawson, eds. Springer, Dordrecht, Netherlands.

Rieu, I., and Powers, S. J. 2009. Real-time quantitative RT-PCR: Design, calculations, and statistics. Plant Cell 21:1031-1033.

Robaglia, C., Durand-Tardif, M., Tronchet, M., Boudazin, G., Astier-Manifacier, S., and Casse-Delbart, F. 1989. Nucleotide sequence of potato virus Y (N Strain) genomic RNA. J. Gen. Virol. 70:935-947.

Rolland, M., Glais, L., Kerlan, C., and Jacquot, E. 2008. A multiple single nucleotide polymorphisms interrogation assay for reliable Potato virus Y group and variant characterization. J. Virol. Methods 147:108-117.
Rotenberg, D., Kumar, N., Ullman, D., Montero-Astúa, M., Willis, D., German, T. and Whitfield, A. 2009. Variation in tomato spotted wilt virus titer in Frankliniella occidentalis and its association with frequency of transmission. Phytopathol 99:404-410.

Rowley, J. S., Gray, S. M., and Karasev, A. V. 2015. Screening potato cultivars for new sources of resistance to Potato virus $Y$. Am. J. Potato Res. 92:38-48.

Singh, M., and Singh, R. P. 1996. Factors affecting detection of PVY in dormant tubers by reverse transcription polymerase chain reaction and nucleic acid spot hybridization. J. Virol. Methods 60:47-57.

Singh, R. P., and Boiteau, G. 1986. Reevaluation of the potato aphid, Macrosiphum euphorbiae (Thomas), as vector of potato virus Y. Am. Potato J. 63:335-340

Singh, R. P., Kurz, J., and Boiteau, G. 1996. Detection of stylet-borne and circulative potato viruses in aphids by duplex reverse transcription polymerase chain reaction. J. Virol. Methods 59:189-196.

Singh, R. P., Valkonen, J. P., Gray, S. M., Boonham, N., Jones, R. A., Kerlan, C., and Schubert, J. 2008. Discussion paper: The naming of Potato virus Y strains infecting potato. Arch. Virol. 153:1-13.

Tjallingii, W. F. 1988. Electrical recording of stylet penetration activities. Pages 95-108 in: Aphids: Their Biology, Natural Enemies and Control, vol. 2B. A. K. Minks and P. Harrewijn, eds. Elsevier, Amsterdam, Netherlands.

Uzest, M., Gargani, D., Dombrovsky, A., Cazevieille, C., Cot, D., and Blanc, S 2010. The "acrostyle": A newly described anatomical structure in aphid stylets. Arthropod Struct. Dev. 39:221-229.

Verbeek, M., Piron, P. G. M., Dullemans, A. M., Cuperus, C., and Van Der Vlugt, R. A. A. 2010. Determination of aphid transmission efficiencies for N, NTN and Wilga strains of Potato virus Y. Ann. Appl. Biol. 156:39-49.

Wang, R. Y., Ammar, E. D., Thornbury, D. W., Lopez-Moya, J. J., and Pirone, T. P. 1996. Loss of potyvirus transmissibility and helper-component activity correlate with non-retention of virions in aphid stylets. J. Gen. Virol. 77: 861-867.

Webster, C. G., Thillier, M., Pirolles, E., Cayrol, B., Blanc, S., and Uzest, M. 2017. Proteomic composition of the acrostyle: Novel approaches to identify cuticular proteins involved in virus-insect interactions. Insect Sci. 24:990-1002.

Zhang, J., Nie, X., Nanayakkara, U., Boquel, S., Giguère, M. A., and Pelletier, Y. 2013. Detection of Potato virus Y from the stylets of a single aphid by one-step reverse transcription polymerase chain reaction. Entomol. Exp. Appl. 147: 93-97. 